\section{INEQUALITY OF THE PUPILS IN TUBERCULAR MENINGITIS.}

To the Editors of THE LANCET.

Sras,--In your issue of the 12 th ult. I notice a letter from my friend Dr. Alderson. The subject-" The Inequality of the Pupils in Tubercular Meningitis"-is one that occupied my attention considerably some time ago, when I had the opportunity of examining the eyes of several children suffering from this disease. Granting that inequality of pupils is liable to exist in these cases, $I$ own that $I$ am somewhat surprised that Dr. Alderson-whom I know to be a very careful observer-should attach such enormous weight to this single symptom. Tubercular meningitis is simply acute tuberculosis affecting (principally) the pia mater at the base of the brain, with serous exudation into the lateral ventricles; and it seems to me that it is a mere accident whether pressure is greater on one side than on the other, or whether it is equal on both sides. To reject the diagnosis of tubercular meningitis because pressure is symmetrical would therefore appear to be going rather too far. I can give Dr. Alderson details of an undoubted case of tubercular meningitis which terminated fatally, in which there was wide dilatation of both pupils, with immobility under the strongest light, and also double optic neuritis. Personally, I should attach greater importance to the fact of dilatation being present (whether equal or unequal), and especially to the insensibility (partial or complete) of the iris under the stimulus of light. Dr. Alderson does not tell us whether he examined the fundi of any of his cases, and whether he found any change therein indicating a descending perineuritis. It would be interesting to bear the opinions of others on these diagnostic points, which is my apology for sending this letter to you instead of direct to my friend.-I am, Sirs, your obedient servant,

$$
\text { A. ST. Clatr Boxton, F.R.C.S., }
$$

Assistant-Surgeon to the Western Ophthalmic

Orchard-street, W., March, 188ĩ. Hospital.

\section{ANATOMY AND PHYSIOLOGY IN CHARACTER. To the Editors of THE LANCET.}

SIRs,-Accept my thanks for your careful analysis of $\mathrm{my}$ recent work. One point your reviewer has misapprehended. I expressly state that the rule for shrewish men and women to have clear, pink skins has many exceptions. My book is so compressed that misapprehensions are perhaps not unnatural. The Saturday Review, for instance, declares that many non-shrewish persons have round backs. I myself said this as clearly as I knew how. I am sure you will permit me to advert to a matter of fact. In matters of opinion I am well aware that I run counter to so much popular belief and feeling that the wide and generous reception already given to my book excites my genuine surprise. I am, Sirs, yours obediently,

Birmingham, March 14th, 1886.

FURNEAUX JORDAN.

\section{VEXATIOUS ACTIONS AGAINST MEDICAL MEN.} To the Editors of THA LANCET.

SIRs,-The following short statement of facts may perhaps serve as a warning to some of my fellow-practitioners, if there are still any who need it, and will in any case, I trust, help to strengthen the hands of those who are striving for the reform of a most unjust law.

One fine day in August, when most of my professional neighbours were enjoying their holidays, I was served with a magistrate's order, directing me to visit and report upon the state of mind of a supposed lunatic. I did as I was ordered, found that the individual was undoubtedly insane, and certified to that effect. Next day she was brought before the magistrate, who satisfied himself by personal examination of the correctness of my opinion, and signed an order for her removal to a public asylum, where she was detained for two months. Some months afterwards I was served with notice of an action, then with a long list of "interrogations"; then one of the plaintiff's witnesses was examined by commission; and at last, after various other distractions and annoyances, was put to the inconvenience of a trial extending over four days, at the conclusion of which the jury without hesitation gave a verdict in $\mathrm{my}$ favour, the judge awarded me "costs," and I was overwhelmed with friendly congratulations. Again an interval of a few months, and $I$ receive a bill for $£ 2408 s .1 d$. The plaintiff professes herself a pauper. I am told that it is open to me to institute proceedings in bankruptcy against her; but I have had enough of law for the present, and even the lawyers do not hold out much prospect of a successful result. There is nothing to be done but to pay the demand as best I can out of hardly-earned savings, and with the hope that the time is not far distant when such flagrant injustice will be a thing of the past.

$$
\text { March, 1887. I am, Sirs, yours truly, }
$$

\section{THE ACCOMMODATION FOR PRISONERS AWAITING TRIAL. \\ To the Editors of THe LANCET.}

SIRs,-I am directed by the Mayor of Marlborough to write to you on the subject of your remarks on the Report of the Committee of Inquiry into the Accommodation for Prisoners awaiting Trial, in your issue of the 12th inst. So far as Marlborough is concerned, there seems to be no doubt that the Committee's Report is founded upon information furnished by the Governor of Devizes Prison of the state of things antecedent to 1885 , and does not take cognisance of alterations and improvements effected by the Town Council since that date. As regards the sanitary arrangements, there has been a complete change, a proper watercloset being now provided in a separate room, and the repulsive practice as quoted by you from the report done away with. The prisoners' room has also been enlarged, and improvements effected in the lighting and warming of it. I may add that the accommodation now provided has been favourably reported on by one of Her Majesty's inspectors, and can compare favourably with that of any other town in the county of Wilts. 1 trust that, for the credit's sake of our town, you will give prominence to this letter.

I am, Sirs, your obedient servant,

$$
\text { E. LLEWELLYN GWILLIM, }
$$

Marlborough, Wilts, March 16th, 1887. Town Clerk.

\section{"PARTIAL ENTEROCELE (IRREDUCIBLE) ASSO- CIATED WITH HYDROCELE OF THE HERNIAL SAC," \\ To the Editors of THE LANCET.}

SIRS,-Since the publication of my case of partial enterocele, Mr. Day, jun., of Harlow, who was present at the operation, has sent me a few facts of importance which add to its interest: "She had not been wearing a truss previouly to the operation, and her local inflammatory symptoms before she was sent up to town had been nil. Since the operation her condition has been excellent, and she has had no further trouble with regard to the rupture."

Marcl, 1887. I am, Sirs, yours sincerely, William Hy. Battle.

\section{LIVERPOOL}

(From our own Correspondent.)

\section{OUR LOCAL ASSIZE COURTS AND THE ACCOMMODATION} FOR PRISONERS.

THe committee appointed by the Government to inquire into the accommodation for prisoners awaiting trial were satisfied with the arrangements made in our Assize Court. The steps from the prisoner's dock lead to a large waitingroom, closely adjoining which are a sufficient number of separate cells, both for male and female prisoners, with every proper sanitary arrangement. These courts were erected in 1854, and it would appear that so far as the prisoners are concerned nothing is required. But, as remarked in previous letters, the accommodation for witnesses is most inadequate, and, as Liverpool is probably not singular in this respect, it is to be hoped that the Government may, now that the prisoners have been considered, inquire into the arrangements made for other persons concerned-the witnesses, the jurors, and all whom justice requires to be present. 